Prepared in cooperation with Gwinnett County, Georgia

Executive Summary and Annotated Bibliography of Selected References From "Microbial and Viral Indicators of Pathogens and Human Health Risks From Recreational Exposure to Waters Impaired by Fecal Contamination" With Related Project Ideas for Gwinnett County, Georgia

Open-File Report 2021-1028 



\section{Executive Summary and Annotated Bibliography of Selected References}

From "Microbial and Viral Indicators of

Pathogens and Human Health Risks From

Recreational Exposure to Waters Impaired

by Fecal Contamination" With Related

Project Ideas for Gwinnett County, Georgia

By Anna M. McKee and Marcella A. Cruz

Prepared in cooperation with Gwinnett County, Georgia

Open-File Report 2021-1028 


\section{U.S. Geological Survey, Reston, Virginia: 2021}

For more information on the USGS - the Federal source for science about the Earth, its natural and living resources, natural hazards, and the environment—visit https://www.usgs.gov or call 1-888-ASK-USGS.

For an overview of USGS information products, including maps, imagery, and publications, visit https://store.usgs.gov/.

Any use of trade, firm, or product names is for descriptive purposes only and does not imply endorsement by the U.S. Government.

Although this information product, for the most part, is in the public domain, it also may contain copyrighted materials as noted in the text. Permission to reproduce copyrighted items must be secured from the copyright owner.

Suggested citation:

McKee, A.M., and Cruz, M.A., 2021, Executive summary and annotated bibliography of selected references from "Microbial and viral indicators of pathogens and human health risks from recreational exposure to waters impaired by fecal contamination" with related project ideas for Gwinnett County, Georgia: U.S. Geological Survey Open-File Report 2021-1028, 10 p., https://doi.org/10.3133/ofr20211028.

ISSN 2331-1258 (online) 


\section{Acknowledgments}

Barbara Seal of the Gwinnett County Department of Water Resources assisted with the development of the scope of work for the review.

We thank Joel Stokdyk and Haley Olds at the U.S. Geological Survey for their reviews. 



\section{Contents}

Acknowledgments …….....................................................................................................................

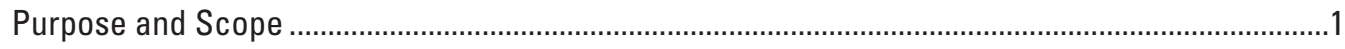

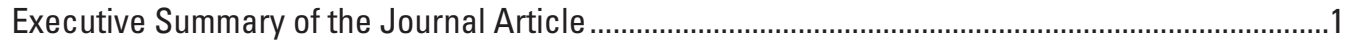

Journal Article-Related Project Ideas for Assessing Human Health Risks, Informing Mitigation Plans, and Guiding Management of Impaired Streams........................................2

Intensive Local Pathogen Screening To Identify Pathogens of Concern and Potential

Environmental Factors Influencing Pathogen Presence or Abundance ......................2

Concurrent Screening for Microbial Source Tracking Markers and Fecal Indicators .............2

Quantitative Microbial Risk Assessments in Practice ................................................................

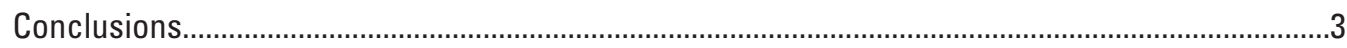

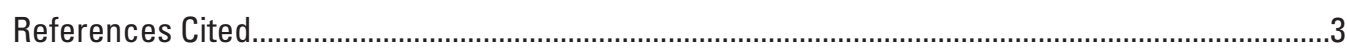

Annotated Bibliography of Selected References From the Journal Article .....................................

\section{Abbreviations}

$\begin{array}{ll}\text { crAssphage } & \text { cross-assembly phage } \\ \text { DNA } & \text { deoxyribonucleic acid } \\ \text { FIB } & \text { fecal indicator bacteria } \\ \text { MST } & \text { microbial source tracking } \\ \text { PCR } & \text { polymerase chain reaction } \\ \text { PMMOV } & \text { pepper mild mottle virus } \\ \text { OMRA } & \text { quantitative microbial risk assessment } \\ \text { qMST } & \text { quantitative microbial source tracking } \\ \text { qPCR } & \text { quantitative polymerase chain reaction } \\ \text { RNA } & \text { ribonucleic acid }\end{array}$





\title{
Executive Summary and Annotated Bibliography of Selected References From "Microbial and Viral Indicators of Pathogens and Human Health Risks From Recreational Exposure to Waters Impaired by Fecal Contamination" With Related Project Ideas for Gwinnett County, Georgia
}

\author{
By Anna M. McKee and Marcella A. Cruz
}

\section{Purpose and Scope}

This document was prepared in cooperation with Gwinnett County, Georgia, to supplement the journal article "Microbial and Viral Indicators of Pathogens and Human Health Risks from Recreational Exposure to Waters Impaired by Fecal Contamination" (McKee and Cruz, 2021). The document includes an executive summary of the article, project ideas for Gwinnett County to enhance its bacterial monitoring program, and an annotated bibliography of selected references from the article. Although tailored to Gwinnett County, the project ideas are based on the state of the science of monitoring for fecal-associated pathogens and pathogen indicators in impaired surface waters and may be of interest to water resources divisions of other municipalities.

\section{Executive Summary of the Journal Article}

Fecal indicator bacteria (FIB; for example, fecal coliforms, Escherichia coli, and enterococci) have been used for decades to monitor for and protect the public from waterborne pathogens from fecal contamination. However, FIB may not perform well at predicting the presence of waterborne pathogens or human health outcomes from recreational exposure to fecal-contaminated surface waters. Numerous factors can influence the relationship between FIB and pathogens or human health outcomes, including the source(s) of contamination, the type of pathogen(s) present, differences in survival and behavior of FIB and pathogens in the wastewater conveyance and treatment process, and varying environmental conditions. Because of this complexity of factors, different indicators, such as source-specific microbial source tracking (MST) markers and viral fecal indicators, have been used as surrogates to possibly better approximate pathogen abundance and human health risk in recreational waters. The performance of these alternative indicators has been mixed, with some promise of viral indicators better approximating viral pathogens than bacterial fecal indicators and of FIB better representing bacterial pathogen and protozoal pathogen presence than human MST markers.

There are numerous unknowns about the behavior and survival of fecal indicators and pathogens in environmental waters, such as propensity to adhere to particles and the effects of temperature and exposure to ultraviolet light on persistence. Developing accurate models to predict pathogen concentrations from fecal indicators in recreational waters will require a better understanding of these unknowns. Current methods and technologies for detecting and quantifying fecal indicators and pathogens are limited because of the rare and patchy nature of pathogens. Technological advances may improve sensitivity for detecting and quantifying pathogens. Many of the assays to detect and quantify fecal indicators and pathogens are polymerase chain reaction (PCR)-based assays, which detect and quantify nucleic acid (in other words, deoxyribonucleic acid [DNA] and ribonucleic acid [RNA]) sequences specific to the target microorganism or virus.

When a specific pathogen is of concern for a recreational waterbody, a practical approach to estimating the likelihood of human health outcomes is the application of quantitative microbial risk assessments (QMRAs). QMRAs can be used to model the likelihood of pathogen-specific human health outcomes from recreational exposure as a function of a surrogate indicator. Inputs for QMRAs include the ratio between the indicator to be monitored and the pathogen of interest, the concentration of the indicator, the amount of water ingested, and the likelihood of the health outcome based on the estimated amount of pathogen consumed.

Although no perfect method exists to assess human health risks in impaired streams, the use of site characteristics or existing data, such as surrounding land use or fecal indicator data, can help inform which approaches may be best suited to provide actionable information. A suggested avenue for 
research is to assess pathogens at sites of interest to determine pathogens of concern. Concurrent assessments of fecal indicators would enable the selection of optimal surrogates (such as FIB) for regular monitoring efforts. Identification of associations between surrogate indicators and pathogens of concern could be used to develop QMRAs for estimating the likelihood of illness from exposure to contaminated waters.

\section{Journal Article-Related Project Ideas for Assessing Human Health Risks, Informing Mitigation Plans, and Guiding Management of Impaired Streams}

The exclusive emphasis in legislation on FIB monitoring has resulted in a prioritization of monitoring for FIB and meeting benchmark FIB standards, as opposed to the intended purpose of indicating human health risk (Field and Samadpour, 2007). The changes in prevalence, number, and diversity of pathogens in a population, as well as differences in dilution, decay rates, and fate and transport between pathogens and pathogen indicators preclude the existence of a single microbial indicator that correlates perfectly with human health risk (Payment and Locas, 2011). Direct monitoring for pathogens generally requires more specialized expertise, equipment, and cost than monitoring for traditional FIB and, therefore, may not be a viable option for some monitoring programs. However, when resources permit, an additional or alternative approach to regulating water quality and protecting swimmers and other recreators would be to identify pathogens of concern in the waterbody and then use targeted pathogen monitoring in combination with MST to develop targeted remediation efforts (Field and Samadpour, 2007). Potential sources of contamination in the watershed could help inform the decision of which initial suite of pathogens to screen for. For example, if agricultural runoff-as opposed to septage or sewage - is known to be the primary source of fecal contamination, zoonotic pathogens would likely be prioritized over human enteric viruses. Studies of the human health risk from exposure to fecal contamination in impaired streams would ideally include site-specific characterization of which pathogens are present, their concentration levels, and how these levels change in relation to hydrologic condition, season, and time. Concurrent sampling for fecal indicators would then help determine which indicators best predict pathogen occurrence and under what conditions those relationships exist. Outlined in the following paragraphs are three potential approaches to assess human health risks from recreational exposure to fecalcontaminated waters and develop targeted mitigation plans to reduce contamination.

\section{Intensive Local Pathogen Screening To Identify Pathogens of Concern and Potential Environmental Factors Influencing Pathogen Presence or Abundance}

Study question: What environmental factors that affect pathogen contamination can inform mitigation efforts?

Approach: Monitor human and zoonotic pathogens over multiple recreational seasons, and model pathogen occurrence with environmental and land use variables.

Outcome: Characterization of pathogen loads and the factors that affect them.

A starting point for research for Gwinnett County, Georgia, would be to determine which pathogens are present over the area of interest and how those pathogens vary in composition and concentration on the basis of measurable environmental and other abiotic variables. As mentioned previously, knowing the source of fecal contamination may help inform the decision of which initial pathogens to screen for. Common waterborne pathogens are listed in table 2 of the subject journal article (McKee and Cruz, 2021). Variables known to affect pathogen concentrations in wastewater effluent and recreational waters include season (Lenaker and others, 2017; Chen and others, 2019), time of day (Vergara and others, 2016), space (Chigor and others, 2014), and hydrologic condition (Eregno and others, 2016; Lenaker and others, 2017), among others. Sites that have been monitored for FIB and have demonstrated historical issues with fecal impairment could help inform the selection of study locations, as could sites with a high frequency of recreational visitors. The approach used by Corsi and others (2016) at beaches in Lake Michigan serves as an example of how results from comprehensive screening for pathogens can be combined with multiple linear regression to investigate environmental factors influencing pathogen levels.

\section{Concurrent Screening for Microbial Source Tracking Markers and Fecal Indicators}

Study question: Which sources or indicators of pathogen contamination can inform risk prediction?

Approach: Screen MST markers and FIB simultaneously with pathogen assessment, and investigate associations between fecal indicators and pathogens.

Outcome: Determination of sensitive surrogates for pathogens of concern.

Assessment of pathogen presence, concentration, and distribution is important for determining the status of pathogens in a study area. However, screening for pathogens presents a number of disadvantages relative to screening for fecal indicators (for example, screening for pathogens is more costly and requires specialized expertise and equipment to process samples). Concurrent screening of fecal indicators 
(bacteria and bacteriophages) and MST markers with pathogen testing of water samples has several benefits. Testing a range of fecal indicators can help determine which indicator acts as the best predictor of pathogen presence, concentration, or both. Monitoring for fecal contamination with the surrogate indicator that is most strongly associated with the pathogen(s) of concern could help optimize estimates of the risk to human health. In addition to potentially predicting the presence or concentration of pathogens of concern, MST markers can help determine likely sources. For example, if human enteric viruses are pathogens of concern, then monitoring for human MST markers can help identify the presence of human contamination even at low levels. When human MST markers are monitored over time in combination with hydrologic data, results can be used to help assess if sewers and septic systems are likely source origins. If the pathogens of concern may have originated from a source other than humans, then determining the sources of contamination is critical for developing and targeting mitigation efforts.

\section{Quantitative Microbial Risk Assessments in Practice}

Study question: What is the current risk of illness for recreators, and which waterbody poses the highest risk?

Approach: Apply QMRA to existing indicator data by using pathogen-indicator ratios published in the literature.

Outcome: Risk-based prioritization of site management.

In the context of recreational waters and risk from accidental ingestion of fecal contamination, QMRAs estimate the likelihood of human illness for a location based on the concentration of the pathogen at a site, the amount of water ingested, and the likelihood of illness given the total amount of pathogen ingested. Because of the involved process of detecting and quantifying pathogens, QMRAs for recreational waters often rely on surrogate fecal indicators to estimate the concentration of the pathogen at the site of interest. Pathogen and fecal indicator ratios are often determined from raw fecal samples or wastewater effluent (for example, see Crank and others, 2019). However, these ratios may change in different environmental settings and on a site-by-site basis (Zhou and others, 2020). If pathogen levels are high enough to quantify in the environmental samples, this approach would provide a more accurate representation of ratios between indicators and pathogens. The deliberate selection of a surrogate fecal indicator with concentrations that are closely associated with concentrations of the reference pathogen would help to optimize the accuracy and utility of the model.

\section{Conclusions}

Fecal contamination in recreational waters in the United States presents a serious risk to human health. Indicators of fecal contamination are generally used for predicting the human health risk from fecal-associated pathogens in recreational waters because of the greater sensitivity of these indicators relative to pathogens, which are often difficult to detect. Despite extensive research into developing methods and indicators for assessing the risk of fecal-associated pathogens to human health, no single indicator has been demonstrated to be an ideal surrogate for these pathogens. For waterbodies where FIB do not accurately reflect the presence or abundance of the pathogens that pose the greatest risk to human health, a continued focus on FIB monitoring may result in the allocation of limited resources to the improvement of water quality at locations where the actual risk to human health may be low. The optimal indicator or individual pathogen for estimating risk from a recreational waterbody will depend on the potential sources of contamination and the variety of pathogens that may be present, as well as logistical constraints. Additional procedures, such as a QMRA, can provide refined estimates of potential illness rates for recreational users of impaired recreational waterbodies and maximize the benefit of resources devoted to monitoring and assessment.

\section{References Cited}

Chen, X., Lang, X.L., Xu, A.-L., Song, Z.-W., Yang, J., and Guo, M.-Y., 2019, Seasonal variability in the microbial community and pathogens in wastewater final effluents: Water, v. 11, no. 12, [article 2586], 14 p., accessed January 2021 at https://doi.org/10.3390/w11122586.

Chigor, V.N., Sibanda, T., and Okoh, A.I., 2014, Assessment of the risks for human health of adenoviruses, hepatitis A virus, rotaviruses and enteroviruses in the Buffalo River and three source water dams in the Eastern Cape: Food and Environmental Virology, v. 6, no. 2, p. 87-98, accessed January 2021 at https://doi.org/10.1007/s12560-014-9138-4.

Corsi, S.R., Borchardt, M.A., Carvin, R.B., Burch, T.R., Spencer, S.K., Lutz, M.A., McDermott, C.M., Busse, K.M., Kleinheinz, G.T., Feng, X., and Zhu, J., 2016, Human and bovine viruses and bacteria at three Great Lakes beaches-Environmental variable associations and health risk: Environmental Science \& Technology, v. 50, no. 2, p. 987-995, accessed January 2021 at https://doi.org/ 10.1021/acs.est.5b04372. 
Crank, K., Petersen, S., and Bibby, K., 2019, Quantitative microbial risk assessment of swimming in sewage impacted waters using crAssphage and pepper mild mottle virus in a customizable model: Environmental Science \& Technology Letters, v. 6, no. 10, p. 571-577, accessed January 2021 at https://doi.org/10.1021/acs.estlett.9b00468.

Eregno, F.E., Tryland, I., Tjomsland, T., Myrmel, M., Robertson, L., and Heistad, A., 2016, Quantitative microbial risk assessment combined with hydrodynamic modelling to estimate the public health risk associated with bathing after rainfall events: Science of the Total Environment, v. 548-549, p. 270-279, accessed January 2021 at https://doi.org/10.1016/j.scitotenv.2016.01.034.

Field, K.G., and Samadpour, M., 2007, Fecal source tracking, the indicator paradigm, and managing water quality: Water Research, v. 41, no. 16, p. 3517-3538, accessed January 2021 at https://doi.org/10.1016/ j.watres.2007.06.056.

Lenaker, P.L., Corsi, S.R., Borchardt, M.A., Spencer, S.K., Baldwin, A.K., and Lutz, M.A., 2017, Hydrologic, land cover, and seasonal patterns of waterborne pathogens in Great Lakes tributaries: Water Research, v. 113, p. 11-21, accessed January 2021 at https://doi.org/10.1016/ j.watres.2017.01.060.
McKee, A.M., and Cruz, M.A., 2021, Microbial and Viral Indicators of Pathogens and Human Health Risks from Recreational Exposure to Waters Impaired by Fecal Contamination: Journal of Sustainable Water in the Built Environment, v. 7, no. 2, [article 03121001], 15 p., accessed March 2021 at https://doi.org/10.1061/JSWBAY.0000936.

Payment, P., and Locas, A., 2011, Pathogens in waterValue and limits of correlation with microbial indicators: Groundwater, v. 49, no. 1, p. 4-11, accessed January 2021 at https://doi.org/10.1111/j.1745-6584.2010.00710.x.

Vergara, G.G.R.V., Rose, J.B., and Gin, K.Y.H., 2016, Risk assessment of noroviruses and human adenoviruses in recreational surface waters: Water Research, v. 103, p. 276-282, accessed January 2021 at https://doi.org/10.1016/ j.watres.2016.07.048.

Zhou, L., Liu, L., Chen, W.-Y., Sun, J.-J., Hou, S.-W., Kuang, T.-X., Wang, W.-X., and Huang, X.-D., 2020, Stochastic determination of the spatial variation of potentially pathogenic bacteria communities in a large subtropical river: Environmental Pollution, v. 264, [article 114683], accessed January 2021 at https://doi.org/10.1016/ j.envpol.2020.114683. 


\section{Annotated Bibliography of Selected References From the Journal Article}

The references summarized herein were selected on the basis of the relevance of subject material to topics discussed within the journal article (McKee and Cruz, 2021) and are categorized by the following subjects: analytical methods; microbial risk assessment; pathogen diversity, microbial indicators, and spatiotemporal variability; and incidence of waterborne pathogens in the United States. The list summarizes key points pertaining to the state of the science in monitoring of fecal-associated waterborne pathogens and of microbial and viral human health risk indicators in streams impaired by fecal contamination. The bibliography is not an exhaustive list. References included in the manuscript "Microbial and Viral Indicators of Pathogens and Human Health Risks from Recreational Exposure to Waters Impaired by Fecal Contamination" were found initially through Google Scholar by using search terms that included but were not limited to the following: "pathogens," "viruses," "fecal indicator," "fecal contamination," "microbial source tracking," "sewage pollution," "freshwater," "recreational water," "environmental water," "quantitative microbial risk assessment," "metabarcoding," "bacteriophage," "coliphage," and "crAssphage." Newly published scientific articles or preprints were discovered from Google Scholar Alerts with selected keywords in the title; selected keywords included "microbial source tracking," "environmental DNA," and "metabarcoding." Scientific papers published in 2015 or later were initially prioritized. References within these papers were used to identify seminal, foundational, and other relevant publications for more indepth information. For articles that were highly relevant, the Google Scholar feature "Cited by ..." was used to look for additional and more recently published articles on the topic. When an additional pertinent keyword was encountered in publications, this term was also searched for in Google Scholar. Publications focusing on freshwater systems were prioritized, although some publications on marine systems and wastewater treatment plants were included.

\section{Analytical Methods}

Bibby, K., Crank, K., Greaves, J., Li, X., Wu, Z., Hamza, I.A., and Stachler, E., 2019, Metagenomics and the development of viral water quality tools: npj Clean Water, v. 2, no. 1, [article 9], 13 p., accessed January 2021 at https://doi.org/ 10.1038/s41545-019-0032-3.

- This article reviews the process of developing a viral fecal indicator, from sample collection and metagenomic analysis to discover potential indicator viruses to monitoring of viral indicators via molecular methods.
- The review includes a summary of human-associated viruses discovered through metagenomics, including Bocavirus, Cosavirus, Klassevirus, cross-assembly phage (crAssphage) and pepper mild mottled virus (PMMOV).

- Research needs and limitations of molecular methods used to identify and monitor viral indicators are discussed.

Bonadonna, L., Briancesco, R., and La Rosa, G., 2019, Innovative analytical methods for monitoring microbiological and virological water quality: Microchemical Journal, v. 150, [article 104160], 8 p., accessed January 2021 at https://doi.org/10.1016/j.microc.2019.104160.

- This article reviews analytical methods used for monitoring bacteria and viruses in waterways, including rapid culture-based methods, cultivation-independent detection methods (for example, flow cytometry, adenosine tri-phosphate, and biosensors), mass spectrometry, and molecular methods (for example, PCR-based methods, isothermal RNA detection, loopmediated isothermal amplification, DNA microarrays, and next generation DNA sequencing).

- Advantages and disadvantages of the different analytical methods for monitoring microbial and virological water quality are discussed.

Bridle, H., Balharry, D., Gaiser, B., and Johnston, H., 2015, Exploitation of nanotechnology for the monitoring of waterborne pathogens - State-of-the-art and future research priorities: Environmental Science \& Technology, v. 49, no. 18, p. 10762-10777, accessed January 2021 at https://doi.org/ 10.1021/acs.est.5b01673.

- This article describes nanomaterials and their use in technology (in other words, nanotechnology).

- It reviews studies on the application of nanotechnology in sampling and detection of waterborne pathogens, including use in optical detection, biosensors, and molecular methods.

- Recommendations for future research directions, such as testing methods across different water types and different pathogens, are discussed.

Haramoto, E., Kitajima, M., Hata, A., Torrey, J.R., Masago, Y., Sano, D., and Katayama, H., 2018, A review on recent progress in the detection methods and prevalence of human enteric viruses in water: Water Research, v. 135, p. 168-186, accessed January 2021 at https://doi.org/ 10.1016/j.watres.2018.02.004. 
- This article reviews the advantages and disadvantages of various methods used to detect human enteric viruses in water.

- Methods for concentrating individual human enteric viruses and multiple microbes in a water sample are reviewed, including virus adsorption and elution, size exclusion via filtration, and coagulation/flocculation.

- Methods for detecting viruses are described, including cell culture methods, PCR-based methods, the integration of cell culturing and PCR.

- Methods for assessing infectivity of viruses are discussed.

- The article reviews quantitative occurrence and genetic diversity of viruses in water.

- The article also outlines the need for and various types of methodological controls, which include the following:

o process controls: culturable surrogate virus is added to the water sample to assess recovery efficiency of the entire viral concentration and detection process;

o molecular process controls: surrogate viral particles are inoculated into the sample immediately prior to DNA extraction;

$o$ and PCR controls: surrogate viral DNA or RNA is added to the extracted product to test efficiency of the PCR-based assay.

Harwood, V.J., Staley, C., Badgley, B.D., Borges, K., and Korajkic, A., 2014, Microbial source tracking markers for detection of fecal contamination in environmental watersRelationships between pathogens and human health outcomes: FEMS Microbiology Reviews, v. 38, no. 1, p. 1-40, accessed January 2021 at https://doi.org/10.1111/15746976.12031.

- This article describes the limitations of FIB for estimating the presence or abundance of pathogens.

- The rationale for conducting MST studies is outlined.

- The article includes definitions of MST marker sensitivity, specificity, limit of detection, and limit of quantification.

- Characteristics of human-associated markers are described, including the performance of human-associated Bacteroidales, Bifidobacterium, Enterococcus faecium esp gene, Methanobrevibacter smithii, Lachnospiraceae, E. coli, $\mathrm{F}^{+} \mathrm{RNA}$ coliphage genotyping, PMMOV, human polyomaviruses, pathogenic viruses, and human mitochondrial DNA.
- The authors summarize interlaboratory comparisons of human-associated marker performance.

- Connections between pathogen detection in water and risks of waterborne illnesses are discussed.

- Sensitivity and specificity of existing animal-specific MST markers are reviewed.

Korajkic, A., McMinn, B.R., and Harwood, V.J., 2018, Relationships between microbial indicators and pathogens in recreational water settings: International Journal of Environmental Research and Public Health, v. 15, no. 12, [article 2842], 39 p., accessed January 2021 at https://doi.org/10.3390/ijerph15122842.

- This review summarizes 73 papers covering 40 years of data linking microbial indicators to pathogen groups or species in freshwater, marine/brackish waters, and swimming pool environments.

Kumar, N., Hu, Y., Singh, S., and Mizaikoff, B., 2018, Emerging biosensor platforms for the assessment of water-borne pathogens: Analyst, v. 143, no. 2, p. 359-373, accessed January 2021 at https://doi.org/10.1039/ C7AN00983F.

- This article reviews biosensor technologies, characterized by transducer types (electrochemical, optical, and piezoelectric biosensors), that are used to detect waterborne pathogens.

- Benefits and challenges of different biosensor technologies are described.

Maurya, V.K., Kumar, S., and Saxena, S.K., 2020, Novel approaches for detecting water-associated pathogens, in Saxena, S.K., ed., Water-associated infectious diseases: Singapore, Springer, p. 73-95, accessed January 2021 at https://doi.org/10.1007/978-981-13-9197-2_9.

- This book chapter describes methods for detecting water-associated pathogens, including FIB, culturebased methods, enzymatic methods, molecular methods, immunology-based methods, nucleic acidbased methods, biosensor-based methods, and nanotechnology-based methods.

McMinn, B.R., Ashbolt, N.J., and Korajkic, A., 2017, Bacteriophages as indicators of faecal pollution and enteric virus removal: Letters in Applied Microbiology, v. 65, no. 1, p. 11-26, accessed January 2021 at https://doi.org/10.1111/ lam.12736.

- The authors of this article reviewed data from 89 published articles from 5 continents and 25 countries on the effectiveness of bacteriophages and FIB as surrogates for enteric viruses. 
- The article reviews concentrations of infectious enteric viruses (viruses were able to be grown in continuous mammalian cell lines), qPCR-quantified adenovirus and norovirus, $\mathrm{F}^{+}$and somatic coliphages, Bacteroides spp. phages, enterococci phages, enterococci, E. coli, and fecal coliforms in human and nonhuman fecal sources after wastewater treatment processes, as well as in freshwater and marine water.

- Infectious enteric viruses had the lowest reported concentrations in freshwater; fecal coliforms had the highest reported concentrations in untreated and treated wastewater and elevated numbers in freshwater.

- Bacteriophage concentrations were higher than infectious enteric viruses and lower than fecal coliform concentrations and were found to be similar to concentrations of infectious viral pathogens in treated wastewater, suggesting that bacteriophage concentrations may be an effective indicator to track the removal of pathogenic viruses in treated water.

U.S. Environmental Protection Agency, 2019, Method 1696Characterization of human fecal pollution in water by HF183/BacR287 TaqMan quantitative polymerase chain reaction (qPCR) assay: U.S. Environmental Protection Agency, Office of Water, EPA 821-R-19-002, [variously paged; 56 p.].

- This Environmental Protection Agency-validated method characterizes human fecal pollution in water by using the human Bacteroides TaqMan quantitative PCR (qPCR) assay, HF183/BacR287.

- Information in the method includes necessary reagents and supplies, sample collection protocol, sample handling and storage, and data analysis and acceptance criteria.

\section{Quantitative Microbial Risk Assessment}

Ahmed, W., Hamilton, K.A., Lobos, A., Hughes, B., Staley, C., Sadowsky, M.J., and Harwood, V.J., 2018, Quantitative microbial risk assessment of microbial source tracking markers in recreational water contaminated with fresh untreated and secondary treated sewage: Environment International, v. 117, p. 243-249, accessed January 2021 at https://doi.org/10.1016/j.envint.2018.05.012.

- This article explains the application of QMRA modeling to predict risk of gastrointestinal illness in swimmers.
- Human-associated markers Bacteroides HF183, Methanobrevibacter smithii nifH, human adenovirus, human polyomavirus, and PMMOV were evaluated as indicators of a substantial health risk from exposure to untreated and secondary sewage in beach water.

- Among the tested markers, Bacteroides HF183 was the most sensitive to sewage, followed by human polyomavirus, PMMOV, human adenovirus, and Methanobrevibacter smithii nifH.

Crank, K., Petersen, S., and Bibby, K., 2019, Quantitative microbial risk assessment of swimming in sewage impacted waters using crAssphage and pepper mild mottle virus in a customizable model: Environmental Science \& Technology Letters, v. 6, no. 10, p. 571-577, accessed January 2021 at https://doi.org/10.1021/acs.estlett.9b00468.

- This article introduces the comprehensive static modeling application, QMRASwim.

- The authors demonstrate the use of the application with crAssphage and PMMOV as surrogates for estimating the risk of gastrointestinal illness resulting from exposure to adenovirus, norovirus, enterovirus, and rotavirus in fecal- contaminated recreational waters.

- The authors used simulated wastewater exposure scenarios to investigate which of the investigated enteric viruses were the primary etiologic agents causing gastrointestinal illnesses.

Based on model output, levels of PMMOV and crAssphage were associated with 30 illnesses per 1,000 bathers, and concentrations were approximately 50 times greater than their limits of detection, indicating that both are sensitive indicators for detecting risk to human health from viral pathogens.

Soller, J., Bartrand, T., Ravenscroft, J., Molina, M., Whelan, G., Schoen, M., and Ashbolt, N., 2015, Estimated human health risks from recreational exposures to stormwater runoff containing animal faecal material: Environmental Modelling \& Software, v. 72, p. 21-32, accessed January 2021 at https://doi.org/10.1016/j.envsoft.2 015.05.018.

- The authors used QMRA models to determine the risk of gastrointestinal illness from pathogens in agricultural stormwater runoff (zoonotic pathogens) in comparison to pathogens in human fecal contamination at a hypothetical beach.

- Pathogens investigated included Cryptosporidium and Giardia spp., Salmonella enterica, E. coli O157, and Campylobacter spp. 
- Enterococci and E. coli were included as predictors of illness in the QMRA.

- Enterococci-based estimated rates of illness were greater than E. coli-based estimated rates of illness.

- Exposure to human fecal-contaminated waters presented greater risk of illness than exposure to fecal contamination from agricultural runoff.

- QMRA analysis indicated that E. coli $\mathrm{O} 157$ was the dominant predicted risk agent in cattle-affected water, Campylobacter and Cryptosporidium spp. were the predicted dominant risk agents in pig-affected water, and Campylobacter jejuni was the predicted dominant risk agent in chicken-affected water.

- Enterococci- and E. coli-based estimated illness rates were greatest from exposure to human contamination, followed by cow manure (30-180 times lower risk of illness relative to human contamination), pig fecal materials (35-65 times lower risk of illness relative to human contamination), and chicken fecal materials (25-6,000 times lower risk of illness relative to human contamination).

Zhang, Q., Gallard, J., Wu, B., Harwood, V.J., Sadowsky, M.J., Hamilton, K.A., and Ahmed, W., 2019, Synergy between quantitative microbial source tracking (qMST) and quantitative microbial risk assessment (QMRA) — A review and prospectus: Environment International, v. 130, [article 104703], 10 p., accessed January 2021 at https://doi.org/ 10.1016/j.envint.2019.03.051.

- This article reviews studies that combined the use of FIB, quantitative microbial source tracking (qMST), and QMRA as a management tool to identify and mitigate fecal contamination in recreational waterbodies.

- The authors summarize QMRA-based estimated risks of gastrointestinal illness as functions of qPCR assays for enterococci, HumM2 (human MST marker), PMMOV, and others.

- Assumptions and limitations of qMST-QMRA studies are discussed.

- The authors identify that a gap in qMST-QMRA research is the need for more research on the development of accurate and reliable relationships between MST markers and pathogens.

\section{Pathogen Diversity, Microbial Indicators, and Spatiotemporal Variability}

Boehm, A.B., Silverman, A.I., Schriewer, A., and Goodwin, K., 2019, Systematic review and meta-analysis of decay rates of waterborne mammalian viruses and coliphages in surface waters: Water Research, v. 164, [article 114898], accessed January 2021 at https://doi.org/10.1016/ j.watres.2019.114898.

- This article presents the results from the Source Identification Protocol Project, which analyzed the specificity and sensitivity of 41 MST assays for 12 possible fecal sources, including ruminants, cows, horses, sheep, pigs, gulls, chicken, pigeons, dogs, humans, sewage, and septage.

- Sixty-four blind fecal samples were screened by 27 laboratories.

- Forty-one MST assays were screened against human, cow, ruminant, dog, gull, pig, horse, and goose fecal samples.

- The most sensitive and specific assays were HF183 Taqman and BacH (human), Rum2Bac and BacR (ruminant), LeeSeaGull (gull), and Pig2Bac (pig).

- This study used next generation DNA sequencing to investigate seasonal trends in microbial community and pathogen diversity and abundance in final wastewater effluents at a Chinese wastewater treatment plant.

- Pathogenic bacteria were found to be most prevalent in summer samples and included Arcobacters spp., Legionella spp., and Mycobacterium spp. as the most dominant species detected.

- Pathogenic bacteria were associated with illnesses including skin, blood, intestinal, and pulmonary infections.

Farkas, K., Adriaenssens, E.M., Walker, D.I., McDonald, J.E., Malham, S.K., and Jones, D.L., 2019, Critical evaluation of crAssphage as a molecular marker for human-derived wastewater contamination in the aquatic environment: Food and Environmental Virology, v. 11, no. 2, p. 113-119, accessed January 2021 at https://doi.org/10.1007/s12560019-09369-1. 
- This study analyzed the effectiveness of crAssphage as a fecal indicator for untreated and treated wastewater, riverine and estuarine water, sediment, and mussel tissue.

- Samples were collected monthly over a year-long period and were analyzed for the crAssphage marker, CPQ_056 TaqMan.

- CrAssphage was present in all sample types and did not exhibit seasonality.

- CrAssphage concentrations were higher than human enteric viruses (norovirus, sapovirus, adenovirus, and polyomavirus) by one to five orders of magnitude across all sample types.

- The authors conclude that crAssphage is an effective indicator for monitoring human wastewater in environmental waters.

García-Aljaro, C., Blanch, A.R., Campos, C., Jofre, J., and Lucena, F., 2019, Pathogens, faecal indicators and humanspecific microbial source-tracking markers in sewage: Journal of Applied Microbiology, v. 126, no. 3, p. 701-717, accessed January 2021 at https://doi.org/10.1111/jam.14112.

- This article reviews background information on and concentrations of pathogens (bacterial, viral, and protozoal), bacterial and viral fecal indictors, and humanassociated markers in sewage reported across studies.

- The origin, diversity, and limitations of various types of human MST markers are also discussed.

Soller, J.A., Schoen, M.E., Bartrand, T., Ravenscroft, J.E., and Ashbolt, N.J., 2010, Estimated human health risks from exposure to recreational waters impacted by human and non-human sources of faecal contamination: Water Research, v. 44, no. 16, p. 4674-4691, accessed January 2021 at https://doi.org/10.1016/ j.watres.2010.06.049.

- This study used QMRAs based on FIB and pathogen concentrations in fecal material from humans, gulls, chickens, pigs, and cattle to determine the relative human health risks from exposure to fecal contamination from different sources.

- Reference pathogens included norovirus, E. coli O157:H7, Campylobacter. jejuni, Salmonella enterica, Cryptosporidium, and Giardia lamblia.

- The health risk from exposure to cow fecal material was similar to that from exposure to human sewage, whereas the health risks from gull, chicken, and pig feces were significantly lower.
Tran, N.H., Gin, K.Y.-H., and Ngo, H.H., 2015, Fecal pollution source tracking toolbox for identification, evaluation and characterization of fecal contamination in receiving urban surface waters and groundwater: Science of the Total Environment, v. 538, p. 38-57, accessed January 2021 at https://doi.org/10.1016/j.scitotenv.2015.07.155.

- This article reviews the detection ratios, detection frequencies, fate, and mobility of various microbial and chemical markers of fecal contamination in surface water and groundwater.

- Statistical analyses were used to determine the effectiveness of microbial and chemical markers for identifying sources of fecal contamination.

- Among the markers that were analyzed, the authors suggest that the MST marker Bacteroides HF183, pharmaceuticals and personal care products, and artificial sweeteners are the best suited for tracking human contamination.

- The authors present a framework for developing a strategy to monitor fecal contamination and inform mitigation and management efforts.

- The authors conclude that the suitability of any single MST or chemical marker is highly variable, depending on location and other factors, and they encourage the combined use of MST and chemical markers to monitor contamination.

Wu, J., Long, S.C., Das, D., and Dorner, S.M., 2011, Are microbial indicators and pathogens correlated? A statistical analysis of 40 years of research: Journal of Water and Health, v. 9, no. 2, p. 265-278, accessed January 2021 at https://doi.org/10.2166/wh.2011.117.

- This article reviews 540 indicator-pathogen correlations from literature published between 1970 and 2009 to assess which indicators best predicted pathogen presence.

- The authors found that no single indicator determined the presence of pathogens in water; however, coliphages, F-specific coliphages, Clostridium perfringens, fecal streptococci, and total coliforms were more likely than other indicators to indicate presence of pathogens.

- Results from multiple linear regression indicated that sample size and pathogen presence were the statistically significant factors affecting the indicatorpathogen relationship. 


\section{Incidence of Waterborne Pathogens in the United States}

Graciaa, D.S., Cope, J.R., Roberts, V.A., Cikesh, B.L., Kahler, A.M., Vigar, M., Hilborn, E.D., Wade, T.J., Backer, L.C., Montgomery, S.P., Evan Secor, W., Hill, V.R., Beach, M.J., Fullerton, K.E., Yoder, J.S., and Hlavsa, M.C., 2018, Outbreaks associated with untreated recreational water-United States, 2000-2014: American Journal of Transplantation, v. 18, no. 8, p. 2083-2087, accessed January 2021 at https://doi.org/10.1111/ajt.15002.

- This article reviews the frequency and etiology of gastrointestinal illness caused by exposure to fecalcontaminated recreational waters in the United States between 2000 and 2014 .

- Public parks and beaches were the most common setting for the 140 recognized outbreaks, with 84 percent of outbreaks occurring after recreation in lake, river, and pond settings.
World Health Organization, 2017, Guidelines for drinkingwater quality - Fourth edition incorporating the first addendum: Geneva, World Health Organization, 564 p., accessed September 23, 2020, at https://www.who.int/water sanitation_health/publications/drinking-water-qualityguidelines-4-including-1st-addendum/en/.

- This World Health Organization document provides guidelines for drinking water quality and includes topics of health-based targets; water safety plans; surveillance methods; and guidelines for microbial, chemical, and radiological aspects; as well as acceptability of taste, odor, and appearance of drinking water.

- Chapter 7, "Microbial aspects," focuses on microbial contaminants in drinking water and diseases contracted through ingestion, inhalation, and dermal contact with contaminated drinking water.

- Topics discussed in chapter 7 include QMRAs, the occurrence of waterborne pathogens, water treatment technologies for pathogen inactivation and removal, and methods for detecting microbial indicators of pathogens. 
For more information about this publication, contact:

Director, South Atlantic Water Science Center

U.S. Geological Survey

1770 Corporate Drive, Suite 500

Norcross, GA 30093

For additional information visit https://www.usgs.gov/centers/sa-water

Prepared by the USGS Science Publishing Network

Reston and Pembroke Publishing Service Centers 
$\frac{\mathbb{7}}{2}$

궁

응.

क⿳亠口冋亍

$\overrightarrow{0}$

足.

言

言

(2)

용.

.

叧

స్

足 